\title{
24. PALYNOLOGY OF THE PLEISTOCENE GLACIAL/INTERGLACIAL CYCLES OF THE AMAZON FAN (HOLES 940A, 944A, AND 946A) ${ }^{1}$
}

\author{
Carina Hoorn ${ }^{2}$
}

\begin{abstract}
The composition and distribution of organic matter in sediments of the Amazon Fan during the Pleistocene glacial/interglacial sequences has been studied using samples from Holes 940A, 944A, and 946A (Ocean Drilling Program Leg 155). The results show that glacial lowstand deposits are characterized by large concentrations of a palynological assemblage composed of Andean and tropical lowland taxa, minor amounts of reworked Paleozoic, Cretaceous, and Tertiary taxa, and large volumes of organic debris (e.g., wood, vessels, epidermis, and cuticles). In general, these intervals do not contain many taxa diagnostic for the lowland savannah areas. In all the studied sites, there is an increase of ferns, fern allies, reworked and corroded palynomorphs, and fungal spores at the time of the last glacial.

Interglacial highstand deposits are instead characterized by low concentrations of the terrigenous palynological assemblage and a predominance of marine microfossils. Although no marked differences exist in the composition of the organic matter along the fan, there is a decrease in the concentration of palynomorphs from proximal (Sites 940 and 944) to distal (Site 946) sites. There is no compositional difference between the levees and the debris flow. The palynological sequences in the Amazon deep sea fan allow us to characterize the composition of the glacial/interglacial intervals and to correlate the last glacial between the different sites. Moreover, they give an indication of the distribution and concentration of palynomorphs within the fan. These palynological data give no indication of major vegetational changes in the drainage basin. If extensive savannah vegetation existed in Amazonia during the Pleistocene glacial intervals, as claimed in the refugia theory, evidence of it was either obliterated or went unrecorded in the sediments of the Amazon Fan.
\end{abstract}

\section{INTRODUCTION}

The Amazon Fan is a large muddy fan that has been active since Miocene times (Damuth and Kumar, 1975; Hoorn et al., 1995). The fan stores sediments from the entire Amazon drainage basin and has a large riverine input of terrigenous organic matter from the Andean region, the lowland savannahs, and the Amazon rainforest. Fan growth has occurred primarily during phases of global sea-level lowstand when the clastic sediments from the drainage basin bypassed the shelf and were transported directly into the submarine fan (Damuth and Kumar, 1975; Manley and Flood, 1988). During these periods of global sea-level lowstand, there was little or no deposition in the Amazon fluvial system and deep incision in the fluvial valleys took place (Muller et al., 1995). However, during the periods of global sea-level highstand, hardly any sediments reached the fan, and deposition took place in the terrestrial riverine and lacustrine environments and on the continental shelf. Pollen transport into the fan and the land-sea correlation is further discussed by Haberle (this volume). One of the main purposes of a palynological study on the Pleistocene sediments of the Amazon Fan is to provide insight into the effect that Pleistocene climatic changes had on vegetation in the Amazon drainage basin. The current debate on the origins of diversity of the Amazon rainforest and its relation to Pleistocene climatic fluctuations (Colinvaux, 1987; Salo et al., 1986; Bush, 1994; Van der Hammen and Absy, 1994) has searched for explanations in the recent geological past. However, Pleistocene (glacial) deposits are rare on the continent and do not provide complete answers.

The Amazon Fan, a sink for Pleistocene glacial sediments, therefore provides an opportunity to examine the nature of glacial vegetation cover in the basin. Moreover, these sediments contain informa-

${ }^{1}$ Flood, R.D., Piper, D.J.W., Klaus, A., and Peterson, L.C. (Eds.), 1997. Proc. ODP, Sci. Results, 155: College Station, TX (Ocean Drilling Program).

${ }^{2}$ Hugo de Vries Laboratory/Centre for Geo-ecological Research (ICG), University of Amsterdam, Netherlands. (Present address: Sultan Qaboos University, College of Science, P.O. Box 36, Al Khod 123, Sultanate of Oman.) milne@gto.net.om tion on the organic matter distribution in a submarine fan in a tropical setting. The main objectives of this paper are to (1) document the palynological composition of the Pleistocene glacial/interglacial sediments within the Amazon Fan and to correlate the palynological signal between the three selected holes (940A, 944A, and 946A), and (2) compare the palynological composition between sediments of the middle and lower fan to determine if a proximal/distal sorting of palynomorphs exists within the fan.

\section{LOCATION AND DESCRIPTION OF THE SELECTED HOLES}

Three sites were chosen to provide an overview of the palynological signal throughout the fan in time and space. Hole 940A (Fig. 1) was drilled in the uppermost middle fan on the eastern flank of the Amazon Channel $\sim 3 \mathrm{~km}$ from, and $100 \mathrm{~m}$ below, the highest levee crest. The recovered interval consists of sediments composed of late Pleistocene levee deposits and is covered by a thin interval of Holocene sediments. The Pleistocene sequence consists of mud with silt and sand laminae and beds, whereas the Holocene cover consists of calcareous mud. This site was chosen for this palynological study because it offers the possibility to closely study the upper part of the last glacial period, and it provides a good base to analyze the palynological assemblages in a near-channel fan environment.

Hole 944A (Fig. 1) was drilled in the lower part of the middle fan on the eastern levee of the Amazon Channel, $2 \mathrm{~km}$ from the channel axis and on the outside of a meander bend. The recovered interval consists of middle and late Pleistocene levee deposits and a debris flow deposit. In the lower part of the hole, an interglacial interval (isotopic Stage 9; Maslin and Mikkelsen, this volume) was recovered.

The Pleistocene sediments are covered by a Holocene section. The Pleistocene sequence consists of mud with silt and sand laminae and beds, whereas the debris flow deposit consists of mud blocks. The Holocene and interglacial sequences consist of calcareous mud. 


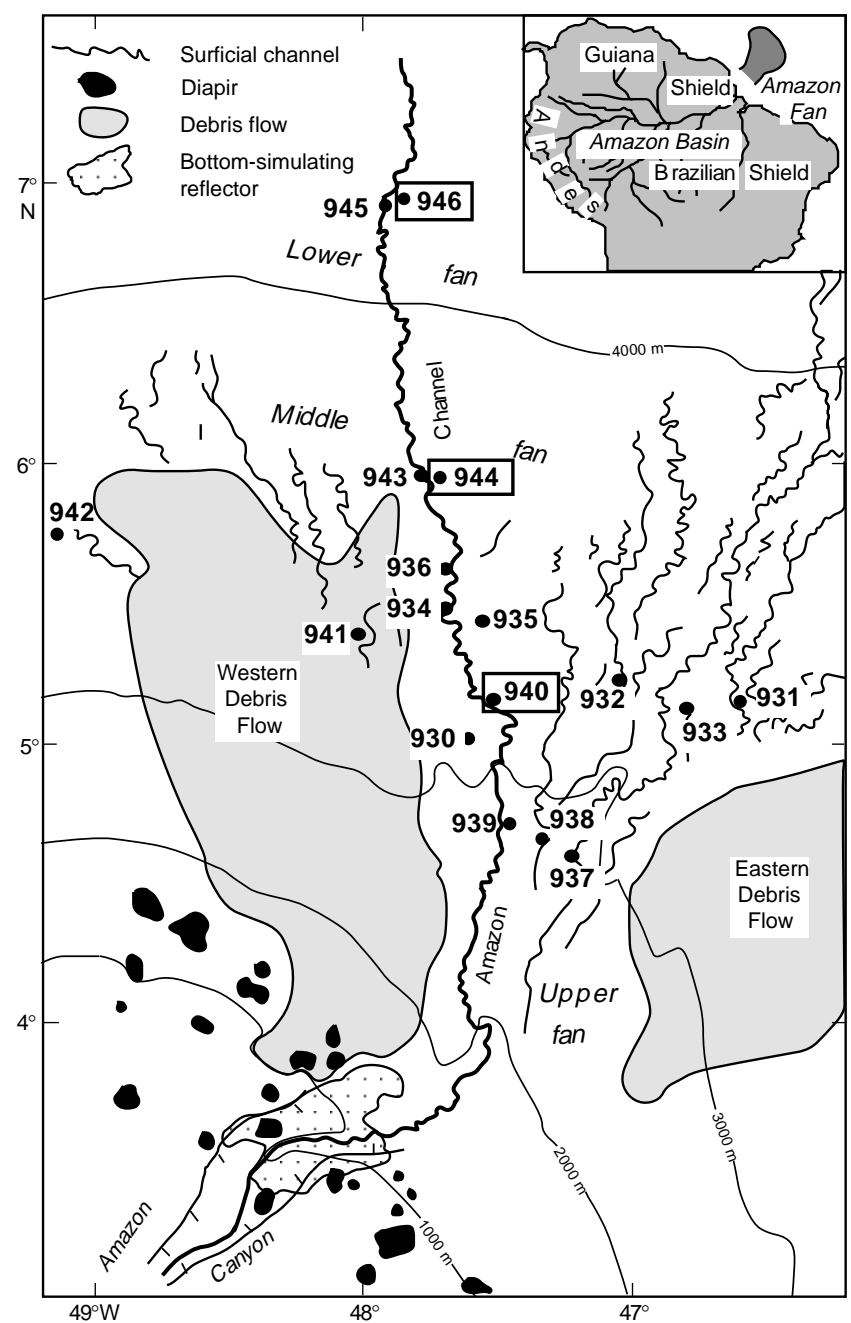

Figure 1. Location of the selected sites in the Amazon Fan, western Atlantic. Sites 940, 944, and 946 are highlighted. Modified from Flood et. al., 1995; modified from Damuth et al., 1988, and Manley and Flood, 1988.

This site was chosen because it contains several levee units and a debris flow and provides a good base to analyze the palynological assemblages in a near-channel fan environment and to compare the results with those of Hole 940A.

Hole 946A (Fig. 1) was drilled near the transition from the middle to lower Amazon Fan, $1 \mathrm{~km}$ from the channel axis on the eastern levee of the Amazon Channel. The recovered interval consists of middle and late Pleistocene muddy levee deposits with a predominance of sands. These sands were formed in a sandy lobe beyond the contemporary channel and were afterward covered by the Amazon levee. Two interglacial intervals are recognized (isotopic Stages 5 and 11; Maslin and Mikkelsen, this volume), separated from each other by a sandy levee. The interglacial intervals and the Holocene cover consist of calcareous mud. This site was selected to compare the palynological composition of the more distal levee units of Hole 946A with the more proximal ones of Holes 940A and 944A. Furthermore, the palynological composition of interglacial vs. glacial deposits could be characterized.

\section{MATERIALS AND METHODS}

For this palynological study, 32 samples were selected from Hole 940A, 40 from Hole 944A, and 30 from Hole 946A. The samples were taken in clusters of two or three and at intervals ranging between 10 and $30 \mathrm{~m}$ to give an overview of the general palynological trends and to establish if marked differences exist according to lithology and subenvironment. Depths are given in meters below seafloor (mbsf) and are not corrected for gas voids.

The samples were processed following the standard procedures of the Hugo de Vries Laboratory. From each sample, $5 \mathrm{~cm}^{3}$ was sieved through a $250-\mu \mathrm{m}$ mesh. One Lycopodium clavatum tablet was added $(13,911$ grains/tablet) to calculate the concentrations of the palynomorphs. The clayey samples were dispersed in a mixture of sodium pyrophosphate $\left(\mathrm{Na}_{4} \mathrm{P}_{2} \mathrm{O}_{7} 10 \mathrm{H}_{2} \mathrm{O}\right)$ in a $10 \%$ solution with $\mathrm{H}_{2} \mathrm{O}$. Finally, bromoform with density $2.0 \mathrm{~g} / \mathrm{cm}^{3}$ was used to separate the organic fraction. The resulting organic residue was mounted in glycerine and sealed with paraffin.

The taxa were identified based on the work of Van der Hammen (1963), Germeraad et al. (1968), Absy (1979), Hooghiemstra (1984), Roubik and Moreno (1991), and Van Waveren (1993). Pollen, spores, marine microfossils, reworked and corroded pollen and spores, and fungal spores were counted, and absolute concentrations were calculated for each group. A pollen sum of 300-400 Quaternary angiosperm pollen grains was used. Not included in the pollen sum were pteridophytic spores, briophytic spores, fungal spores, reworked pre-Quaternary and/or corroded pollen and spores, marine microfossils, and algae. In samples where the pollen concentrations were very low, a minimum sum of 100 pollen grains was accepted. Samples with a sum below 100 were considered unreliable and discarded from the main palynological diagram. Finally, the size distribution of the organic particles was determined measuring the maximum diameter of $\sim 400$ particles/sample and then converting them into phi units as explained in Lorente (1986).

Differences in concentration and pollen percentages between this study and the one carried out by Haberle (this volume) concerned the curves of the smaller pollen grains such as the Combretaceae/Melastomataceae, Urticaceae/Moraceae, and Cecropia. Small pollen grains are more abundant in Haberle's samples. This is probably due to differences in the processing techniques that were used. Palynological results compare well only when processing techniques are identical.

The palynological diagrams (Figs. 2, 3) were made with the computer applications Tilia and Tilia Graph 2.00 (Grimm and Troostheide, 1994). The diagrams of Holes 940A, 944A, and 946A represent $\sim 80$ individual taxa (Figs. $2 \mathrm{~A}-\mathrm{C}$ ). These taxa were grouped according to their present geographical occurrence and ecological affinity (e.g., Van der Hammen and Gonzalez, 1960; Van der Hammen, 1963; Van der Hammen et al., 1973; Absy, 1979; Hooghiemstra, 1984; Duivenvoorden and Lips, 1995; A.M. Cleef, pers. comm., 1995). The following groups were distinguished: Andean-Paramo, Subandean-Tropical Lowland Forest, Lowland Savannah, and Coastal. A concentration diagram for each hole represents the absolute concentration curves of pollen, spores, reworked and corroded pollen and spores, marine microfossils, and fungal spores (Figs. 3A-C). These concentration curves give an estimate of the terrigenous influx in the proximal and distal parts of the fan. A cumulative diagram of a size distribution analysis of the organic particles of Hole 944 is also shown (Fig. 4). Finally, a correlation scheme (Fig. 5) summarizes different data showing the lithology, the ages based on paleomagnetic excursions (Cisowski and Hall, this volume) and micropaleontological dating (Maslin and Mikkelsen, this volume), and the seven zones (A-G) based on frequencies of certain sporomorphs.

\section{DESCRIPTION AND INTERPRETATION OF THE PALYNOLOGICAL DIAGRAMS}

The palynological assemblages of the Pleistocene sediments in the Amazon Fan are composed of a large number of pollen and spores representative of the tropical vegetation in the Amazon drainage basin (Fig. 2). Common taxa include the Andean related elements $\mathrm{Al}$ nus, Hedyosmum, and Podocarpus and the Subandean and Tropical 
Lowland Forest related taxa such as Alchornea, Mauritia, Malpighiaceae, Palmae, Combretaceae/Melastomataceae, and Sapotaceae. In addition, there are many taxa common in a wide range of vegetation types such as Gramineae, Compositae, Myrtaceae, and Ilex. Noticeably low is the occurrence of the coastal genus Rhizophora and the savannah genera Byrsonima and Curatella.

The palynological assemblages are largely dominated by fern, fern allies, and fungal spores that form the most important indication of any change in the hinterland. The most abundant spores are Polypodiaceae and Cyatheaceae. Andean-related fern and moss spores such as Cyathea cuspidata, Cyathea horrida, Lophosoria, Anthoceros, Adiantaceae, Aspleniaceae, and Thelypteridaceae were also observed. The large range of fungal spores was not differentiated and is represented as a single group in the palynological diagrams.

In addition to the Quaternary assemblage, a considerable number of reworked pollen and spores from Paleozoic, Cretaceous, and Tertiary formations were found that were grouped as "reworked preQuaternary." Among these were Paleozoic megaspores, gymnosperms, and acritarchs, Cretaceous dinoflagellate cysts and pollen such as Spinozonocolpites and Buttinia andreevi, and Tertiary pollen and spores such as Echitriporites trianguliformis, Verrutricolporites rotundiporus, Grimsdalea magnaclavata, and Crassoretitriletes vanraadshoovenii. Next to the curve "reworked pre-Quaternary," are two curves indicating the percentages of corroded pollen and spores of Quaternary age. The relatively large concentrations of these corroded pollen and spores of Quaternary age give an indication of the strong effect of weathering due to transport from the continent into the deep sea environment.

The occurrence of Notofagus in Hole 946, a southern South American taxon, is apparently related to another path of long-distance transport and suggests the influence of the North Brazil Coastal Current, transporting pollen from more southerly regions into the deep sea fan. The presence of Pinus in Hole 944A (also observed at other sites in Haberle's study) is yet unexplained.

The palynological assemblages have an extremely homogeneous character and do not allow us to distinguish zones based on the changing composition of the pollen assemblage. However, the palynological diagrams (Figs. 2, 3) were divided into seven zones (A$\mathrm{G})$ based on the frequencies of fern, fern allies, fungal spores, and marine microfossils. These zones, combined with the ages provided by Maslin and Mikkelsen (this volume) and Cisowski and Hall (this volume) allow us to correlate the sites and demonstrate the consistency of the palynological signal within the fan (Fig. 5).

Zone A is characterized by abundances of fungal spores (all sites), Cyatheaceae and Polypodiaceae, and a predominance of Aspleniaceae and Adiantaceae (Holes 944A and 946A). Additionally, a predominance of corroded pollen and spores was observed in Hole 944A and relatively lower percentages of Gramineae in Hole 944A. Zone B has, in comparison to Zone A, relatively lower values of fern, fern allies, and fungal spores (all holes), and the percentages of Gramineae are slightly higher (Hole 944A). Based on the paleomagnetic and micropaleontological dating of Hole 946A (Cisowski and Hall, and Maslin and Mikkelsen, both this volume) these zones belong to the last glacial interval. Based on the date and stratigraphic position of the Lake Mungo paleomagnetic excursion (ca. $30 \mathrm{ka}$ ), Zone A is probably younger than $30 \mathrm{ka}$.

Zones $\mathrm{C}, \mathrm{D}$, and $\mathrm{F}$ represent the interglacial intervals (isotopic Stages 5, 9, and 11, Holes 944A and 946A; Maslin and Mikkelsen, this volume). These zones are characterized by spikes of marine microfossils such as copepod egg and jaw fragments, microforaminifers, tintinnids, and low concentrations of terrigenous palynomorphs in Zones D and F. Relatively higher concentrations of terrigenous palynomorphs were observed in Zone $\mathrm{C}$, particularly in the group of reworked pre-Quaternary and corroded pollen and spores.

The middle Pleistocene Zones E and G are situated below the isotopic Stages 9 and 11 respectively. Zones E and G are similar to Zone $\mathrm{B}$ though concentrations of terrigenous palynomorphs are higher in G.
No zone was defined for the Holocene section, which, in terms of palynological composition, resembles the earlier interglacial intervals. Moreover, pollen sums of those samples which fall in the Holocene are too small to allow representation in the playnological diagrams.

\section{DISTRIBUTION AND CONCENTRATION OF THE PALYNOMORPHS}

The three Holocene samples and the samples of the three earlier interglacial intervals (isotopic Stages 5, 9, and 11, Holes 944A and 946A; Maslin and Mikkelsen, this volume) have very low concentrations of terrigenous palynomorphs $\left(<200\right.$ grains $\left./ \mathrm{cm}^{3}\right)$ and relatively high concentrations of marine microfossils such as copepod fragments, foraminifers, dinoflagellate cysts, and tintinnids.

The glacial intervals have large concentrations of terrigenous palynomorphs ranging from pollen and spores to large fragments of wood and seeds. The finer fractions of plant debris include woody fragments, vessels, cuticles, epidermis, fungal remains, and resins. Concentrations of pollen, pteridophytic and fungal spores, corroded pollen and spores, reworked pre-Quaternary pollen and spores, and marine microfossils were calculated and are shown in Figure 3A-C.

A decrease in concentration of terrigenous palynological assemblage was observed between the proximal Sites 940 and 944 (middle fan) and the more distally located Site 946 (lower fan). This is particularly noticeable in Zones A and B (last glacial), which are represented in all of the three sites. Pollen concentrations in the glacial intervals in the proximal sites range from $\sim 300$ to 3500 grains $/ \mathrm{cm}^{3}$, whereas at the distal site 300-2500 grains $/ \mathrm{cm}^{3}$ were counted. Pteridophytic spore concentrations fluctuate between $\sim 250$ and 8500 grains $/ \mathrm{cm}^{3}$ at the proximal sites vs. a maximum of $\sim 2500$ grains $/ \mathrm{cm}^{3}$ at the distal site. Even more striking are the concentration values of the fungal spores that are 1,000-50,000 grains $/ \mathrm{cm}^{3}$ at Holes $940 \mathrm{~A}$ and $944 \mathrm{~A}$, and $500-10,000 \mathrm{gr} / \mathrm{cm}^{3}$ at Hole 946A. In addition, in Hole 940A massulae of the freshwater fern Azolla were observed together with slightly larger amounts of pollen and spores clusters. This suggests that transport of these large, composed particles was limited to the more proximal sites. The relative decrease of spores from proximal to distal sites suggests some selective transport.

In his study of the Orinoco delta and shelf sediments, Muller (1959) describes a seaward decrease in the concentration of pollen and spores. Moreover, he shows that fungal spores travel out farther on the shelf because of their small size. This is essentially the same pattern that is observed in the Amazon Fan.

No pronounced difference in concentrations were observed according to the environment of deposition (e.g., levee and debris flow). However, concentrations seem to be slightly higher in the mud samples and lower in the sandy mud samples. Finally, a pilot study on the granulometry of the organic particles in Hole 944A shows that in sandy mud, organic particles ranging from fine to coarse sand occur, and that, in the mud, grain sizes between very fine silt to fine sand prevail (Fig. 5). This suggests a size sorting of the organic matter particles according to the lithology and the sedimentary environment within the fan.

\section{DISCUSSION}

A result of this investigation is the observation that Pleistocene sediments of the Amazon Fan provide only circumstantial evidence about the history of the drainage basin. The palynological assemblage in the fan deposits form a homogeneous mixture of pollen and spore taxa of the vegetation types that at present occur in the drainage basin, plus reworked pollen and spores, and marine microfossils. The homogenized palynological signal thus gives no conclusive answer to the question of what happened during the late Pleistocene to a specific area in the drainage basin such as the Amazon rainforest. If a de- 
A

940A Pollen Diagram

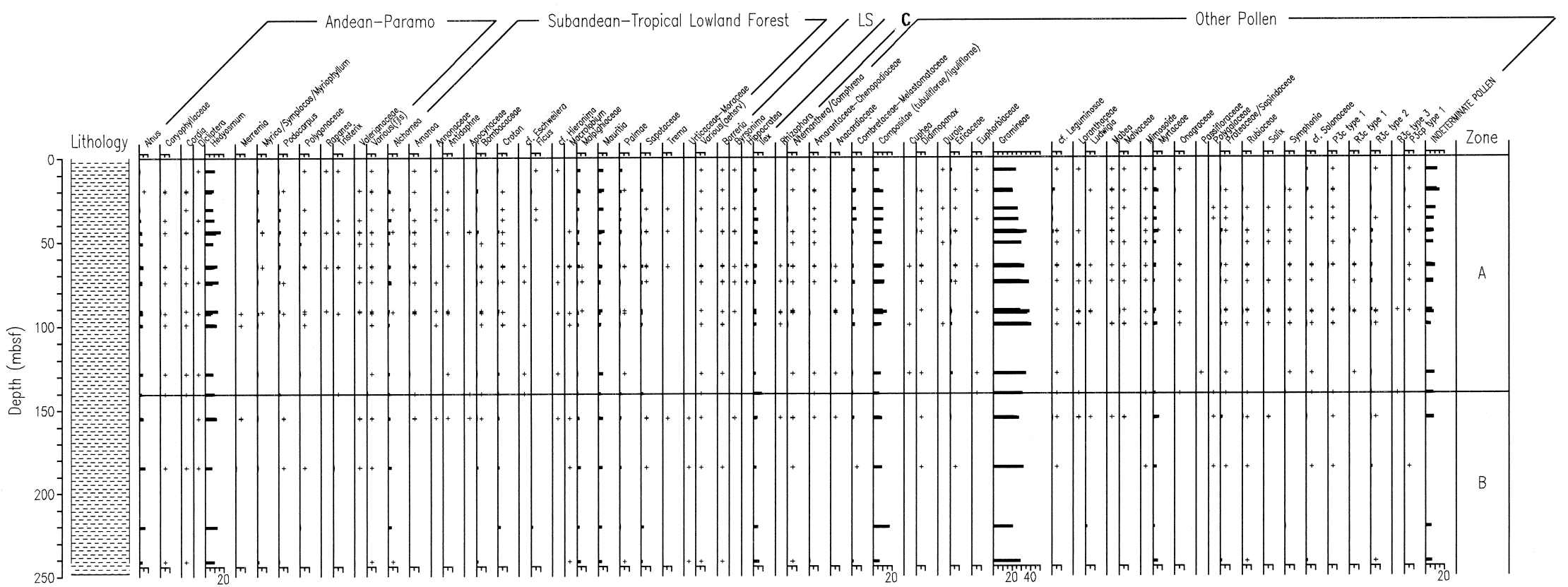

Pollen Sum $=100 \%$

Figure 2. Palynological diagram for (A) Hole 940A, (B) Hole 944A, and (C) Hole 946A. Areas: AP = Andean/Paramo, LS $=$ Lowland Savannah, C $=$ Coastal, and MO = Marine Organisms. Andean Paramo/various zones: $\mathrm{D}=$ Dodonea, $\mathrm{F}=$ Fuschia, $\mathrm{J}=$ Juglans, $\mathrm{L}=$ Lepidium, $\mathrm{Q}=$ Quercus, $\mathrm{S}=$ Spatiphyllum, and $\mathrm{W}=$ Weinmannia. Subandean/Tropical Lowland Forest various zones: $\mathrm{A}=$ Aeschynomene, $\mathrm{B}=$ Byttneria, $\mathrm{D}=$ Dalechampia, $\mathrm{E}=$ Eriosema, $\mathrm{H}=$ Humiria, $\mathrm{h}$ ' = Hybiscus, $\mathrm{s}=$ Sapium, $\mathrm{t}=$ Tournefourtia, $\mathrm{v}=$ Virola, and $\mathrm{r}=$ Rhus. $+=<1 \%$. 


\section{A (continued)}

940A Pollen Diagram

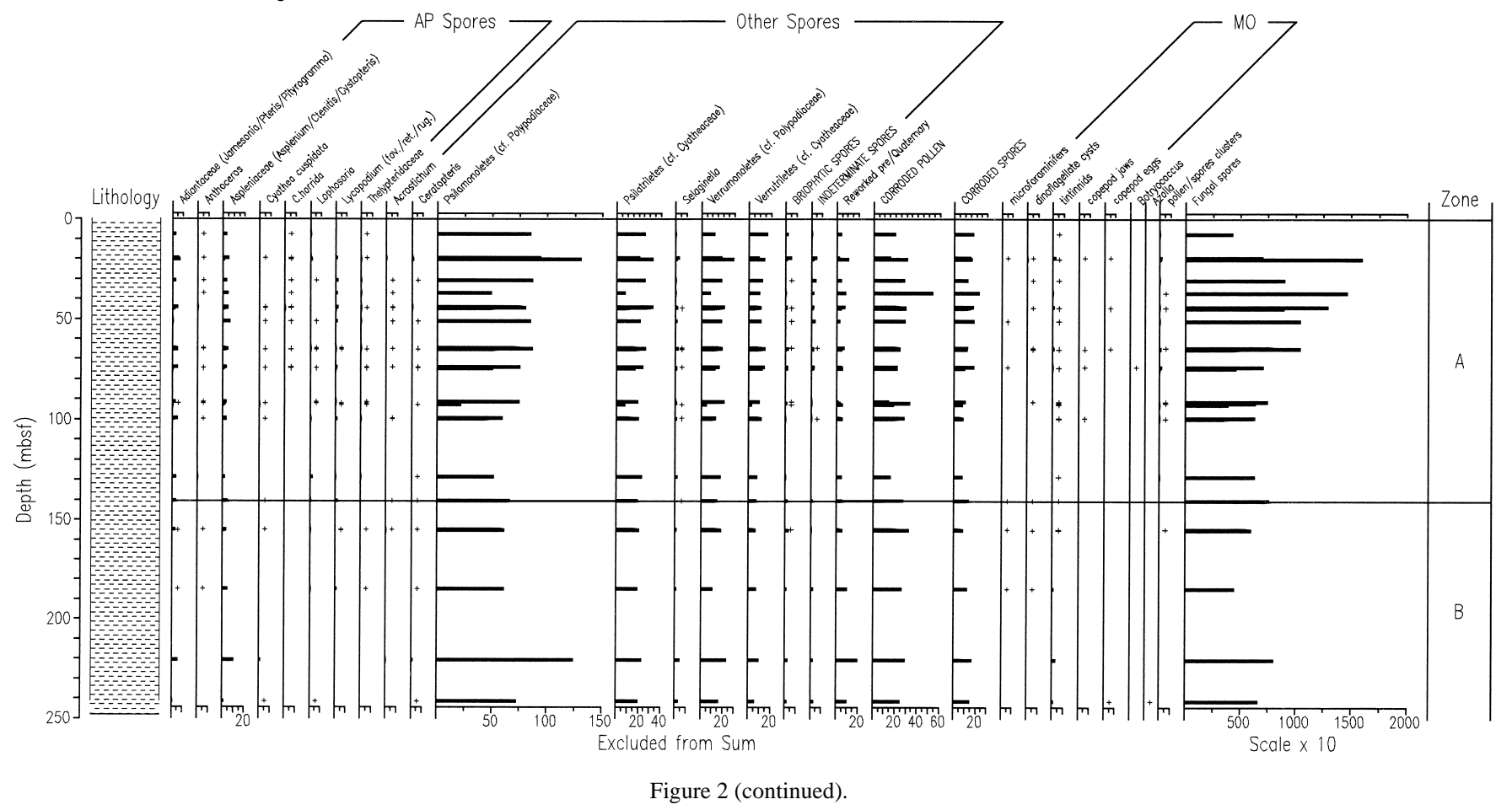


B

944A Pollen Diagram

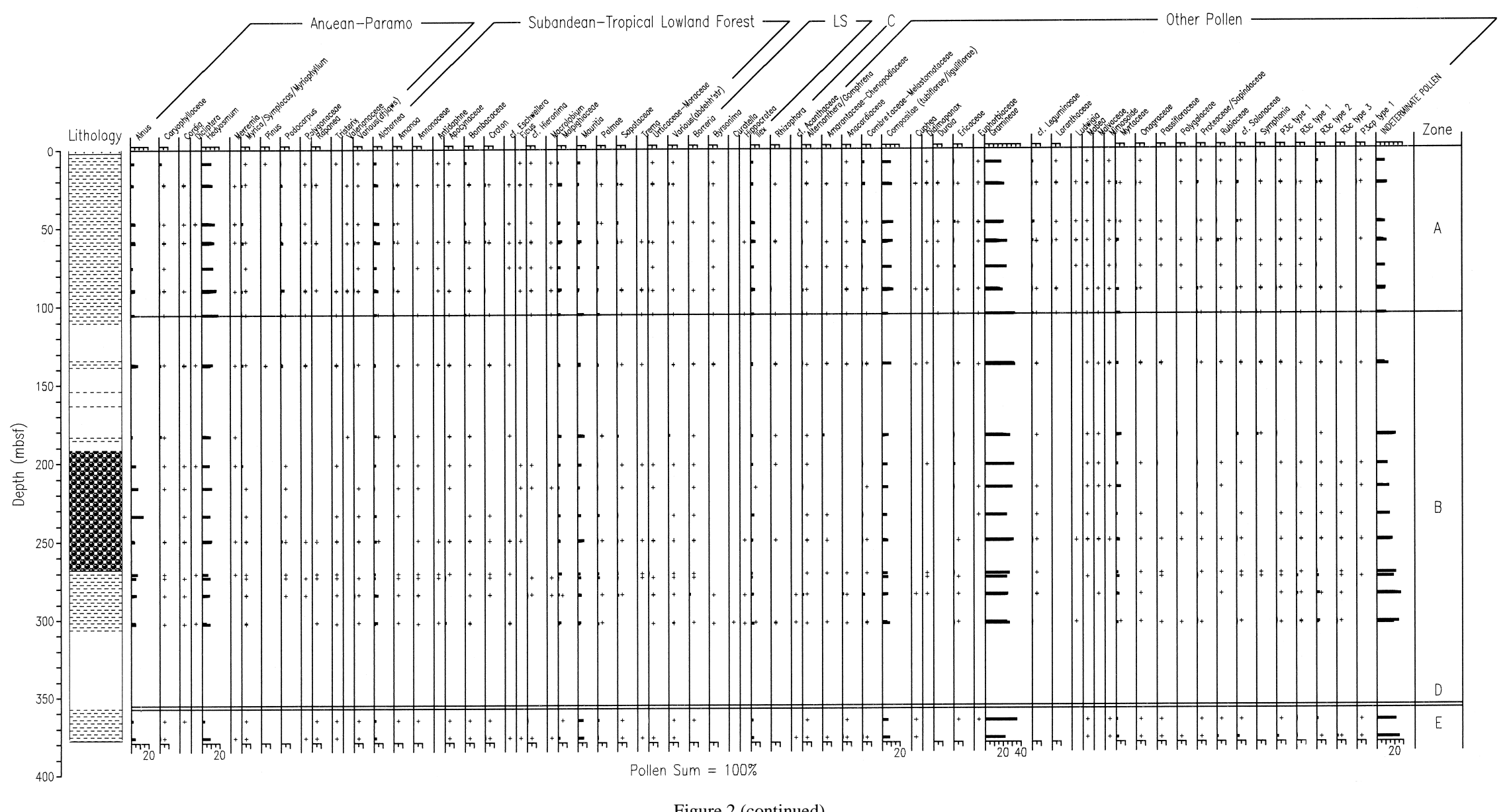

Figure 2 (continued) 


\section{B (continued)}

944A Pollen Diagram

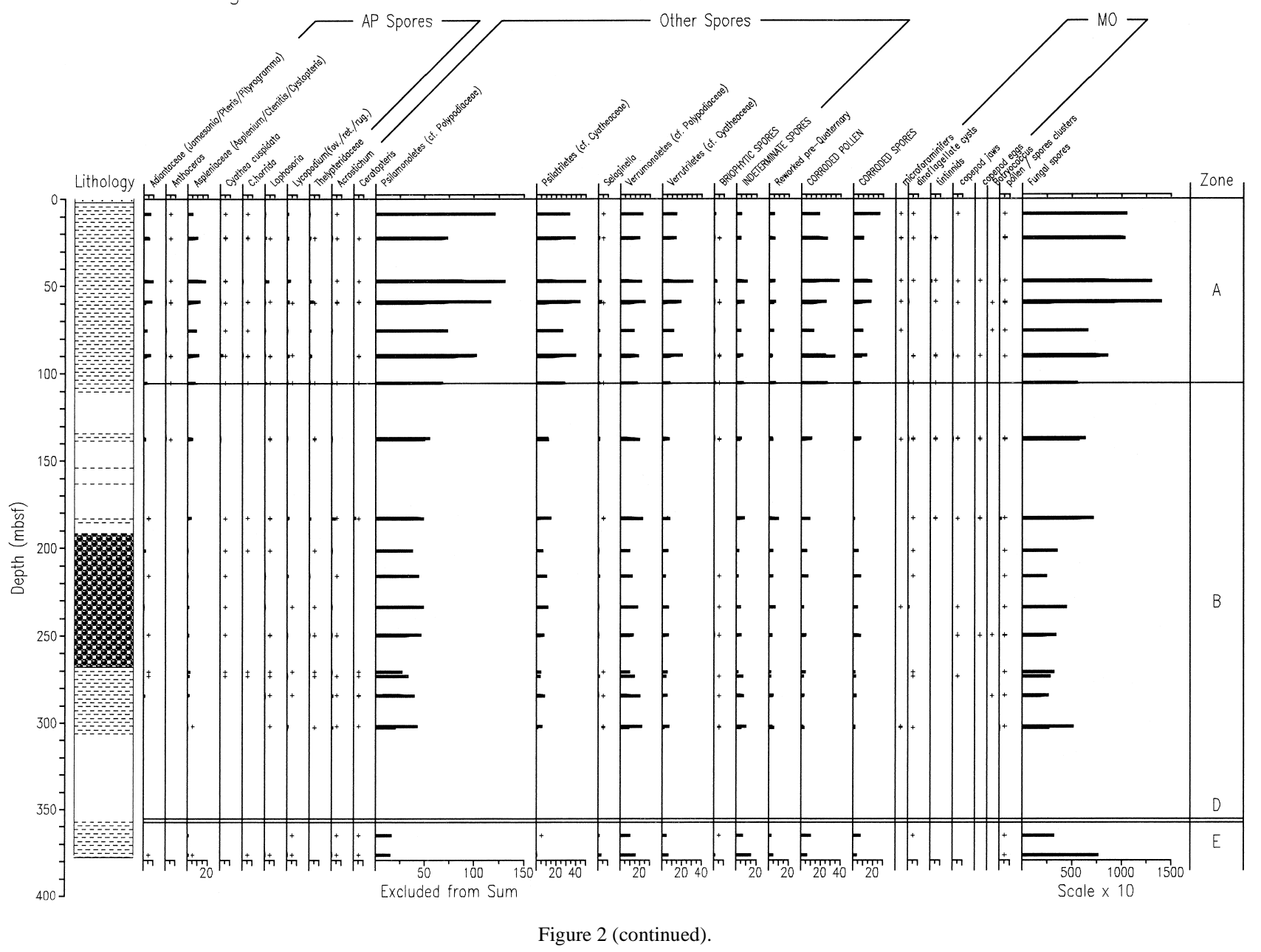


c

946A Pollen Diagram

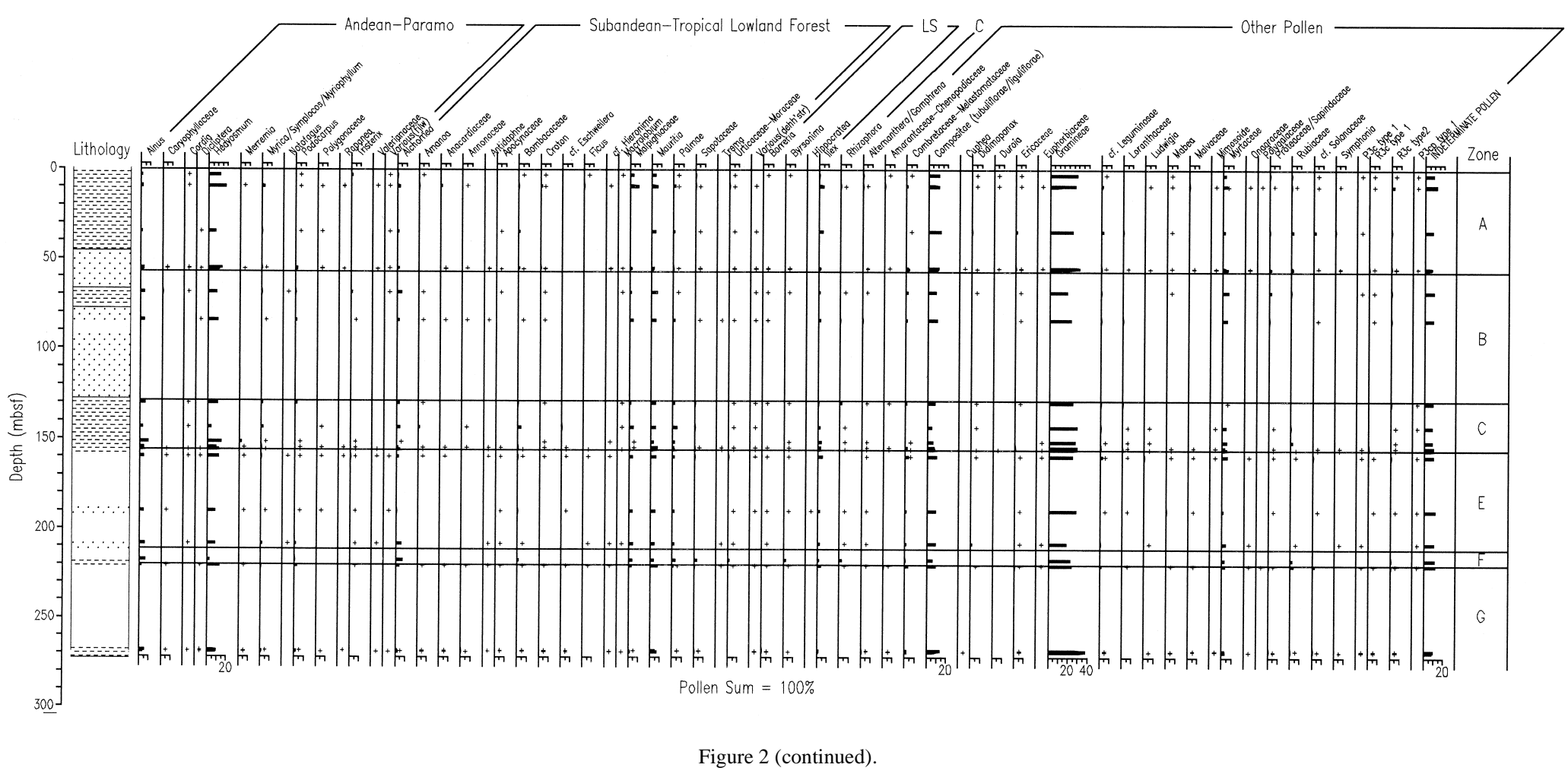




\section{C (continued)}

946A Pollen Diagram

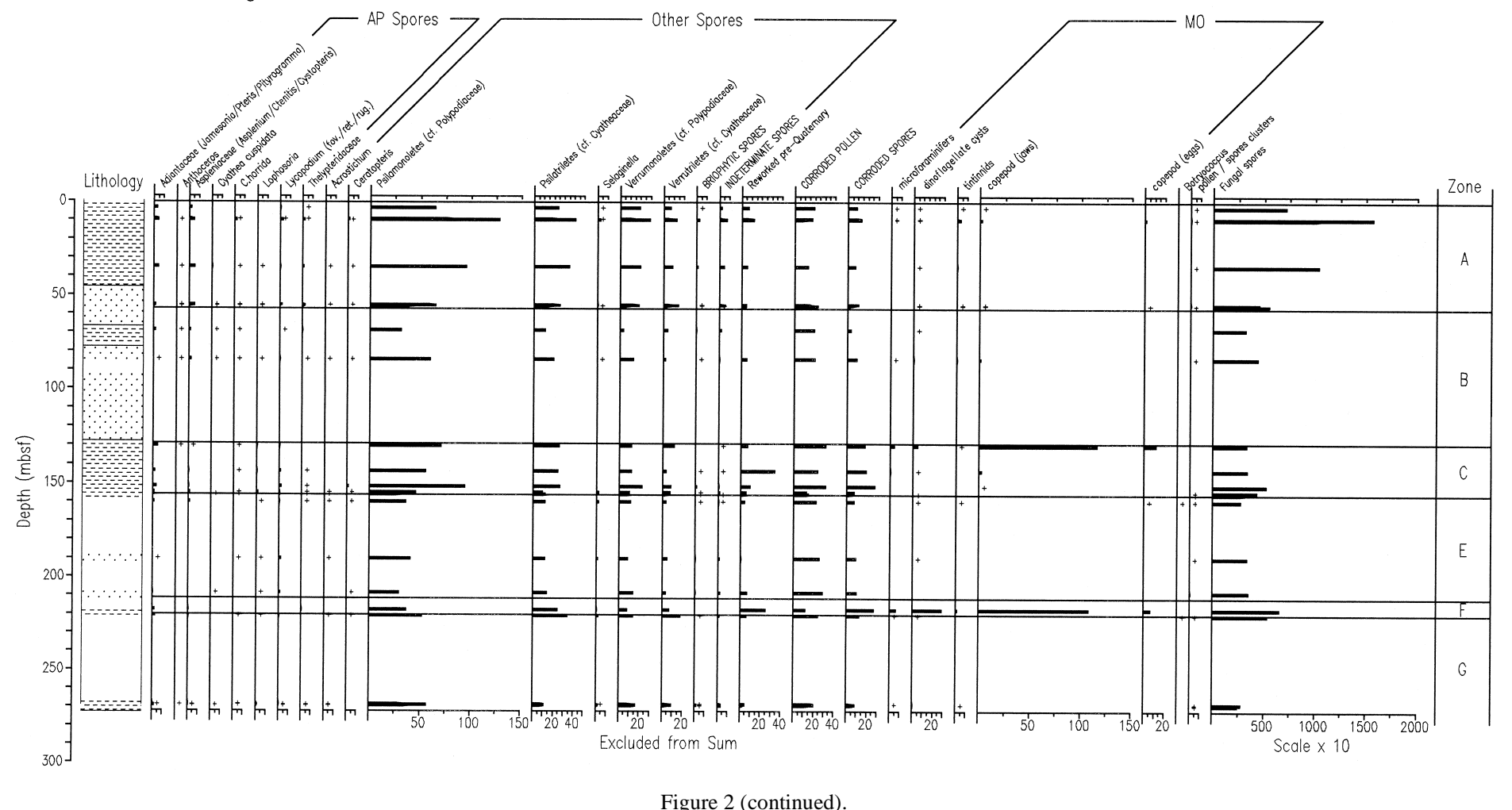

Figure 2 (continued) 
A 940A Concentration Diagram

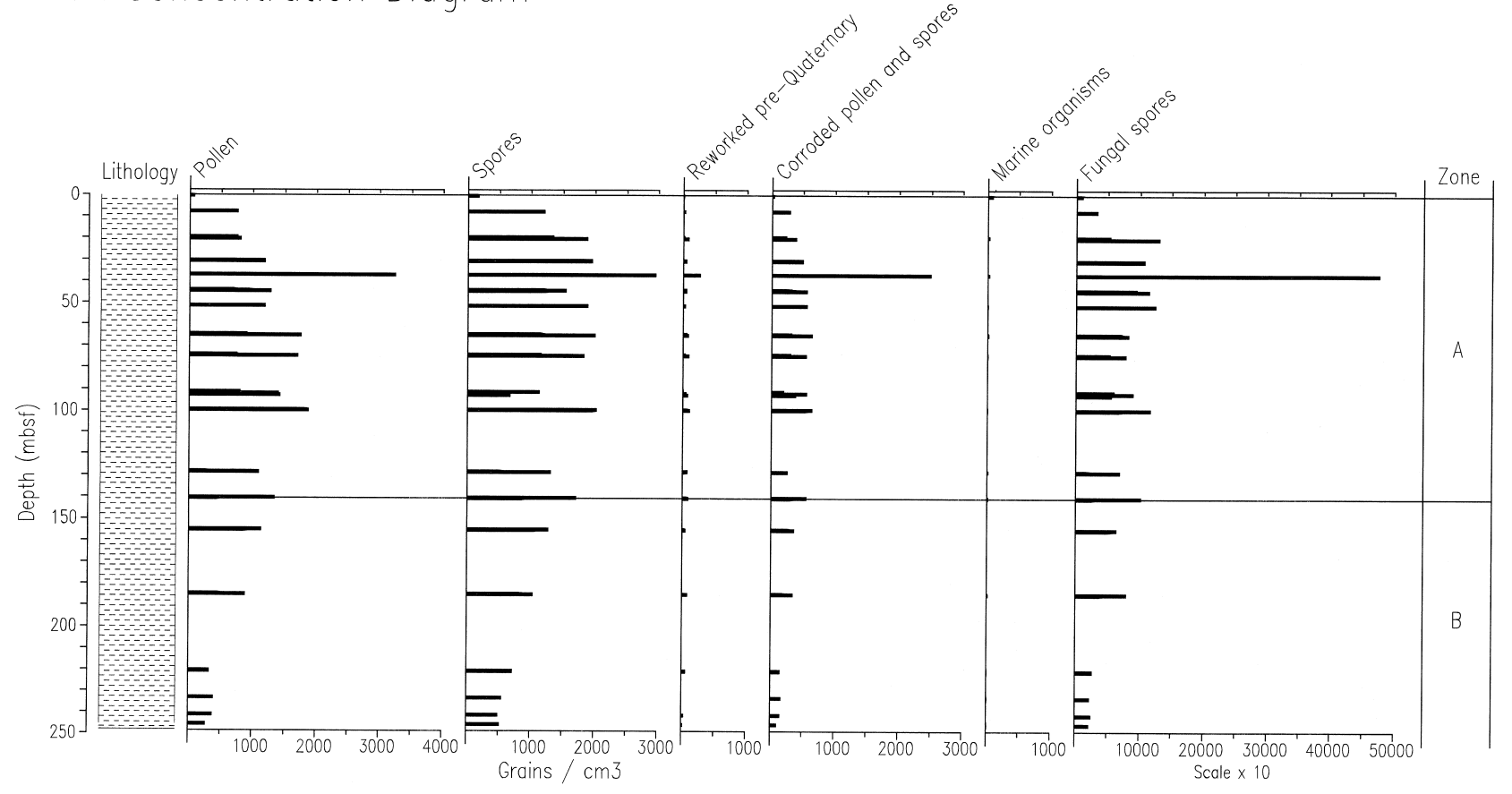

Figure 3. Concentration diagram for (A) Hole 940A, (B) Hole 944A, and (C) Hole 946A.

crease of the rainforest and an expansion of the savannah vegetation occurred during the Pleistocene glacial intervals, as claimed in the refugia theory (Haffer, 1969; Absy and Van der Hammen, 1976; Van der Hammen and Absy, 1994), there is no evidence for this in the pollen composition of the samples from the Amazon Fan.

An increase in the savannah area in the Amazon lowlands during the Pleistocene would imply for the fan sediments an increase of pollen of savannah woodland taxa and herbs such as Gramineae and Compositae. However, savannah woodland taxa such as Curatella and Byrsonima relate to edaphic conditions and occur in low percentages in the fan sediments. Moreover, pollen of herbs such as Gramineae and Compositae, which predominate in the fan sediments, occur in a wide range of environments such as the Andean highlands, floating meadows in the Amazon river, along the riversides, and in open savannahs. An increase in any of these groups thus would not necessarily relate to large-scale vegetation change in the Amazon lowlands.

Nevertheless, an important signal in the palynological sequences of the Amazon Fan was recognized in the curves representing the ferns, fern allies, and fungal spores. These curves show a marked increase during the last glacial. The increase of these spores could be due to a number of reasons. One possible explanation could be an deterioration of the climate (cold, dry conditions) during this period resulting in a stronger erosion in the hinterland. Subsequently, ferns and fern allies may have proliferated in this barren landscape, while destruction of the peat layers in the drainage basin caused an increased release of fungal matter. This palynological signal is comparable to observations made by Poumot (1989) in an earlier study on Neogene tropical marine settings. This study reports on increases in fern and fungal spores during periods of sea-level lowstand.

Earlier work on the Quaternary history of South America pointed out that, during the late Pleistocene, the last glacial maximum constituted a period of particularly cold and dry climate (Van Geel and Van der Hammen, 1973; Kuhry, 1988; Absy et al., 1991; Van der Hammen et al., 1992; Servant et al., 1993; Heusser and Shackleton, 1994). Moreover, Van't Veer et al. (1995) show that in the Andes these cold climatic conditions are reflected in the palynological assemblages by high values of Quercus, Weinmannia, Podocarpus, Hedyosmum, Melastomataceae, Cyatheaceae, and monolete pteridophytic spores. The palynological signals observed in this work and by Haberle (this volume) seem to confirm this.

Haberle compared the palynological composition of Holocene Amazon River and shelf sediments together with Pleistocene Amazon Fan deposits and observed a general decrease of Andean coldadapted taxa (Podocarpus, Hedyosmum, and Alnus) between the last glacial and the Holocene. Haberle's land-sea correlation suggests that the extreme climatic conditions of the glacial periods caused an expansion of the Andean cold-adapted taxa. In addition to this, the present study shows that in the Amazon Fan, the last glacial is consistently represented by an increase of ferns, fern allies, and fungal spores, though an increase in Andean-related ferns was also noticed. Both Haberle's study and this one contribute to the discussion of climatic change in northern South America. However, conclusive answers about the effects of climatic change on the vegetational composition in Amazonia cannot be found in the Amazon Fan and have to be sought in the Amazon region itself.

\section{CONCLUSIONS}

Four important conclusions can be drawn from this palynological study.

1. The glacial lowstand deposits of the Amazon Fan, as observed in Holes 940A, 944A, and 946A, contain high concentrations of terrigenous palynomorphs composed of Andean montane and tropical lowland pollen and spore taxa, with minor amounts of reworked Paleozoic, Cretaceous, and Tertiary taxa, and large volumes of organic debris (e.g., wood, vessels, epidermis, and cuticles). Interglacial highstand deposits instead are characterized by low concentrations of terrigenous palynomorphs and high concentrations of marine microfossils.

2. Seven zones have been distinguished based on the frequencies of fern, fern allies, and fungal spores. From these zones, A and 
B

944A Concentration Diagram

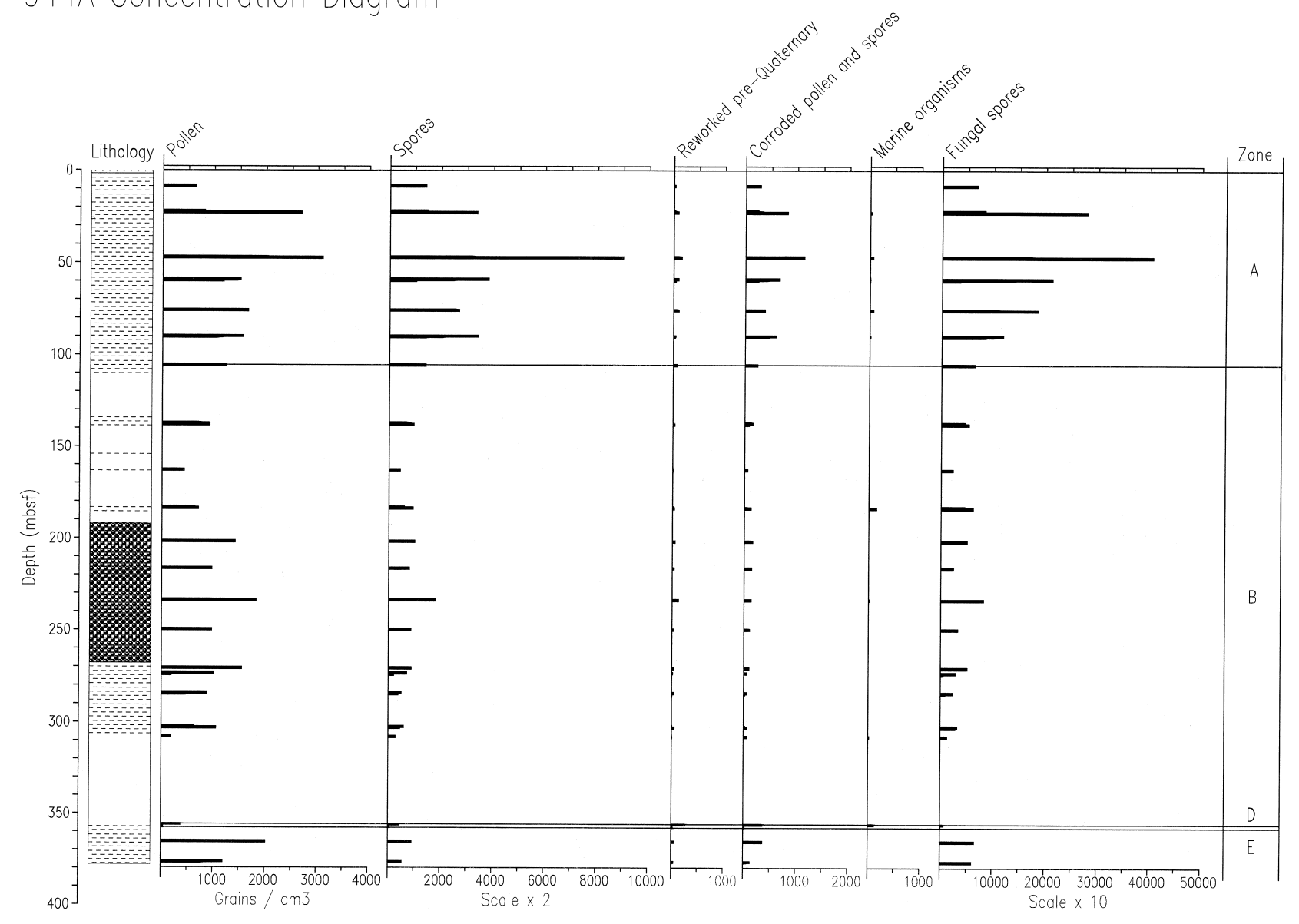

\section{C}

\section{A Concentration Diagram}

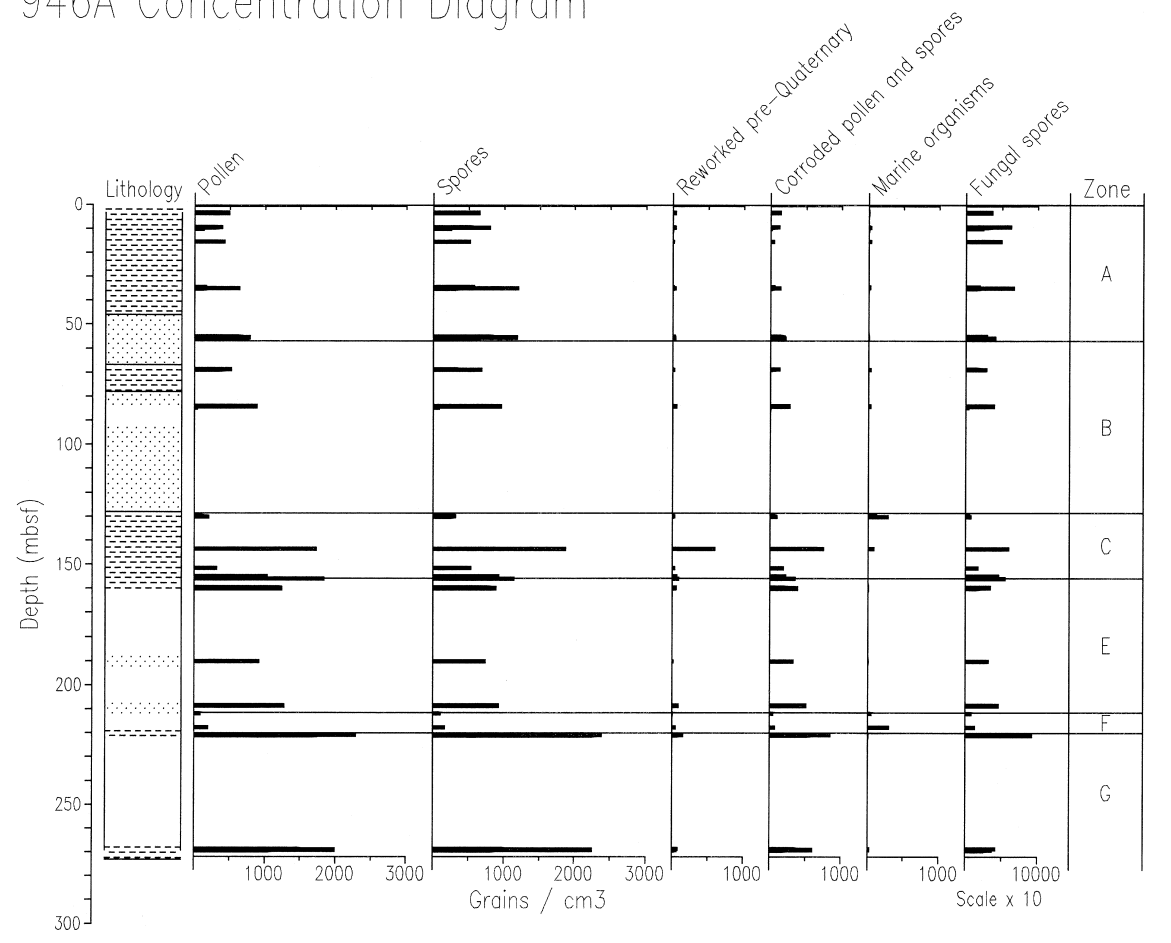

Figure 3 (continued). 


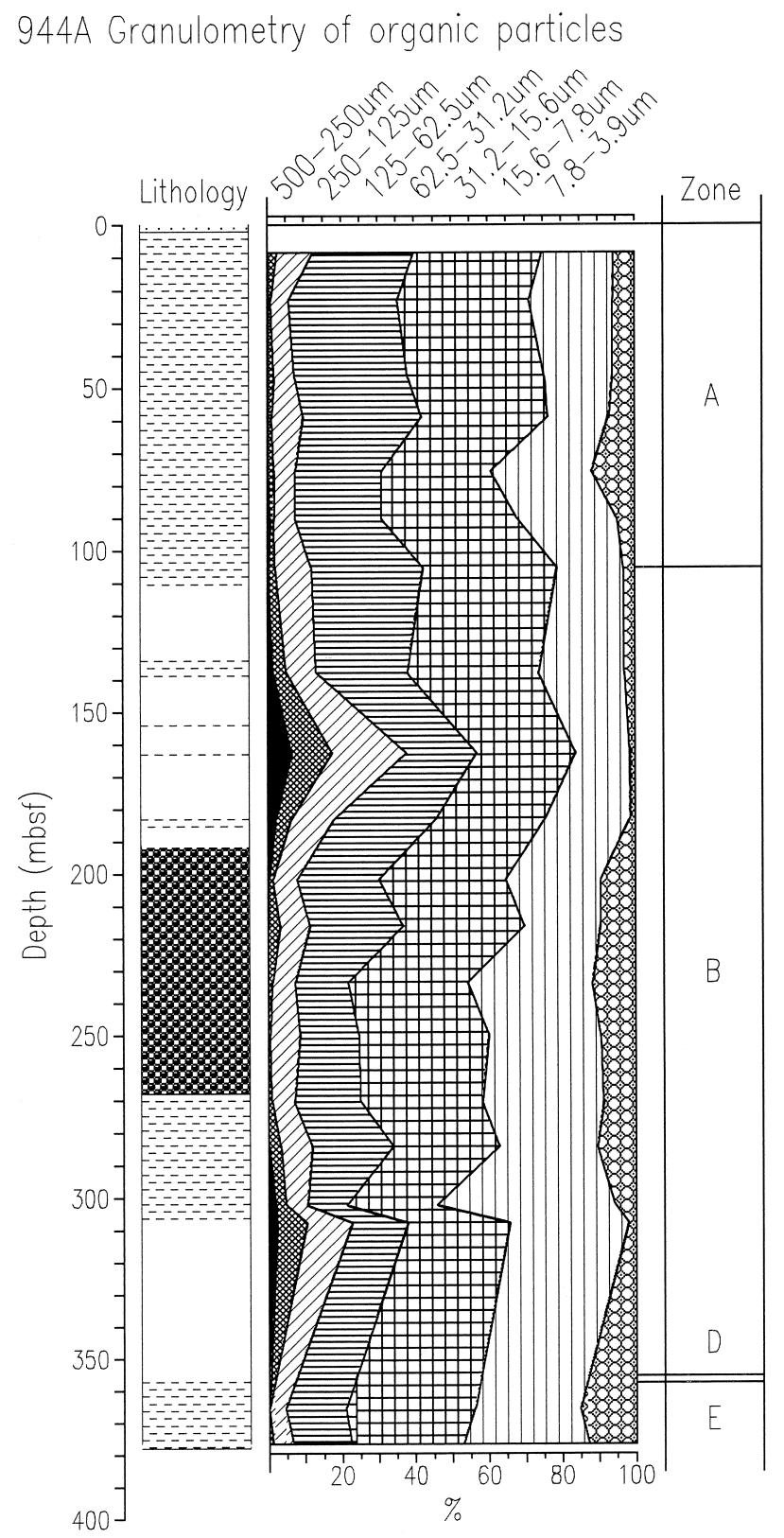

Figure 4. Cumulative diagram showing the granulometric distribution of the organic particles for Hole 944A (phi scale).

B correlate with the last glacial period. Zone A is younger than $30 \mathrm{ka}$ (Hole 946) and is characterized by a relatively high representation of ferns, fern allies, fungal spores, and corroded pollen and spores. The reason for the increase in spores is not clear. One explanation could be stronger erosion in the hinterland due to climatic cooling. Destruction of peaty layers and proliferation of ferns and fern allies over barren areas could in this way cause an increase of pteridophytic and fungal spores in the fan.

3. Zones A and B show a seaward decrease in the concentration of terrigenous palynomorphs from the middle fan to lower fan. Furthermore, concentrations and granulometry of the organic particles vary according to the lithology and sedimentary environment within the fan. Sand-rich lithologies have low concentrations and large-sized organic particles, whereas muddominated lithologies have high concentrations and small- sized organic particles. Finally, the occurrence of Notofagus in Hole 946A suggests the influence of the North Brazil Coastal Current, transporting pollen from more southerly regions into the Amazon Fan.

4. The palynological assemblage in the fan deposits is a homogeneous mixture of pollen and spore taxa of many vegetation types that at present occur in the drainage basin. This homogenized pollen signal does not present indications of large-scale vegetational changes in the drainage basin. If changes in the vegetation of the Amazon lowlands occurred during the Pleistocene glacial intervals, they were either obliterated or not recorded in the fan. To unambiguously test the current hypothesis on the vegetation cover of the Amazon lowlands during the Pleistocene, a wide range of data from land, shelf, and fan should be compared.

\section{ACKNOWLEDGMENTS}

I thank Alastair Milne for his numerous contributions to this work, particularly concerning the palynological diagrams. Henry Hooghiemstra, Bas van Geel, and Simon Haberle are thanked for valuable discussions on tropical Quaternary palynology. Elly Beglinger and Annemarie Phillip are acknowledged for processing the palynological slides, and Jody dos Santos is thanked for her support in all sorts of practical and technical matters.

\section{REFERENCES}

Absy, M.L., 1979. A palynological study of Holocene sediments in the Amazon Basin [Ph.D. thesis]. Univ. of Amsterdam.

Absy, M.L., Cleef, A.M., Fournier, M., Martin, L., Servant, M., Siffedine, A., Ferriera da Silva, M., Soubies, S., Suguio, K., Turcq, B., and Van der Hammen, T. 1991. Mise en evidence de quatre phases d'ouverture de la forêt dense dans le sud-est de l'Amazonie au cours des 60000 dernières années. Première comparaison avec d'autres régions tropicales. $C . R$. Acad. Sci. Ser. 2, 312:673-678.

Absy, M.L., and Van der Hammen, T., 1976. Some palaeoecological data from Rondonia, southern part of the Amazon Basin. Acta Amazon., 6:293-299.

Bush, M.B., 1994. Amazonian speciation: a necessarily complex model. $J$. Biogeogr., 21:5-17.

Colinvaux, P., 1987. Amazon diversity in light of the paleoecological record. Quat. Sci. Rev., 6:93-114.

Damuth, J.E., and Kumar, N., 1975. Amazon cone: morphology, sediments, age and growth pattern. Geol. Soc. Am. Bull., 86:863-878.

Damuth, J.E., Flood, R.D., Knowsmann, R.O., Belderson, R.H., Gorini, M.A., 1988. Anatomy and growth patterns of Amazon deep-sea fan as revealed by long-range side-scan sonar (GLORIA) and high-resolution seismic studies. AAPG Bull., 72:885:911.

Duivenvoorden, J.F., and Lips, J.M., 1995. A land-ecological study of soils, vegetation, and plant diversity in Colombian Amazonia [Ph.D. thesis]. Tropenbos Ser., 12:438.

Flood, R.D., Piper, D.J.W., and Shipboard Scientific Party, 1995. Introduction. In Flood, R.D., Piper, D.J.W., Klaus, A., et al., Proc. ODP, Init. Repts., 155: College Station, TX (Ocean Drilling Program), 5-16.

Germeraad, J.H., Hopping, C.A., and Müller, J., 1968. Palynology of Tertiary sediments from tropical areas. Rev. Palaeobot. Palynol., 6:189-348.

Grimm, E.C., and Troostheide, C.D., 1994. Tilia 2.00, program for plotting palynological diagrams: (Springfield) Illinois State Museum.

Haffer, J., 1969. Speciation in Amazonian forest birds. Science, 165:131137.

Heusser, L., and Shackleton, N.J., 1994. Tropical climatic variation on the Pacific slopes of the Ecuadorian Andes based on a 25,000-year pollen record from deep-sea sediment core Tri 163-31B. Quat. Res., 42:222225.

Hooghiemstra, H., 1984. Vegetational and climatic history of the high plain of Bogota, Colombia: a continuous record of the last 3.5 million years [Ph.D. thesis]. Dissert. Botan., 79:368.

Hoorn, C., Guerrero, J., Sarmiento, G.A., and Lorente, M.A., 1995. Andeantectonics as a cause for changing drainage patterns in Miocene northern South America. Geology, 23:237-240. 
Kuhry, P, 1988. Palaeobotanical-palaeoecological studies of tropical high Andean peatbog sections (Cordillera Oriental, Colombia) [Ph.D. thesis]. Dissert. Botan., 116:241.

Lorente, M.A., 1986. Palynology and palynofacies of the Upper Tertiary in Venezuela [Ph.D. thesis]. Dissert. Botan., 99:222.

Manley, P.L., and Flood, R.D., 1988. Cyclic sediment deposition within Amazon deep-sea fan. AAPG Bull., 72:912-925.

Muller, J., 1959. Palynology of Recent Orinoco Delta and Shelf sediments. Micropaleontology, 5:1-32.

Muller, J., Irion, G., Nunes de Melho, J., and Junk, W., 1995. Hydrological changes of the Amazon during the Last Glacial/Interglacial cycle in Central Amazonia (Brazil). Naturwissenschaften, 82:232-235.

Poumot, C., 1989. Palynological evidence for eustatic events in the tropical Neogene. Bull. Cent. Rech. Explor. -Prod. Elf-Aquitaine, 13:437-453.

Roubik, D.W., and Moreno, J.E., 1991. Pollen and spores of Barro Colorado Island. Monogr. in Syst. Bot. of the Miss. Bot. Garden, 36:269.

Salo, J.S., Kalliola, R., Hakkinen, I., Makinen, Y., Niemela, P., Puhakka, M., and Coley, P.D., 1986. River dynamics and the diversity of Amazon lowland forest. Nature, 322:254-258.

Servant, M., Maley, J., Turq, B., Absy, M.L., Brenac, P., Fournier, M., and Ledru, M.P., 1993. Tropical forest changes during the Late Quaternary in African and South American lowlands. Global Planet. Change, 7:25-40.

Van der Hammen, T., 1963. A palynological study on the Quaternary of British Guiana. Leidse Geol. Meded., 29:125-180.

Van der Hammen, T., and Absy, M.L., 1994. Amazonia during the last glacial. Palaeogeogr., Palaeoclimatol., Palaeoecol., 109:247-261.
Van der Hammen, T., Duivenvoorden, J.F., Lips, J.M., Urrego, L.E., and Espejo, N., 1992. Late Quaternary of the middle Caqueta River area (Colombian Amazonia). J. Quat. Sci., 7:45-55.

Van der Hammen, T., and Gonzalez, E., 1960. Holocene and Late Glacial climate and vegetation of Paramo de Palacio (Eastern Cordillera, Colombia, South America). Geol. Mijnbouw, 39:737-746.

Van der Hammen, T., Werner, J.H., and Van Dommelen, H., 1973. Palynological record of the upheaval of the Northern Andes: a study of the Pliocene and Lower Quaternary of the Colombian Eastern Cordillera and the early evolution of its High-Andean biota. Rev. Palaeobot. Palynol., $16: 1-122$.

Van Geel, B., and Van der Hammen, T., 1973. Upper Quaternary vegetational and climatic sequence of the Fuquene area (Eastern Cordillera, Colombia). Palaeogeogr., Palaeoclimatol., Palaeoecol., 14:9-92.

Van't Veer, R., Ran, E.T.H., Mommersteeg, H.J.P.M., and Hooghiemstra, H., 1995. Multivariate analysis of the middle and late Pleistocene Funza pollen records of Colombia. Meded. Rijks Geol. Dienst., 52:195-212.

Van Waveren, I.M., 1993. Planktonic organic matter in surficial sediments of the Banda sea (Indonesia) - A palynological approach [Ph.D. thesis]. Univ. of Utrecht, Geol. Ultraiect., 104:237.

Date of initial receipt: 11 December 1995

Date of acceptance: 21 May 1996

Ms 155SR-226

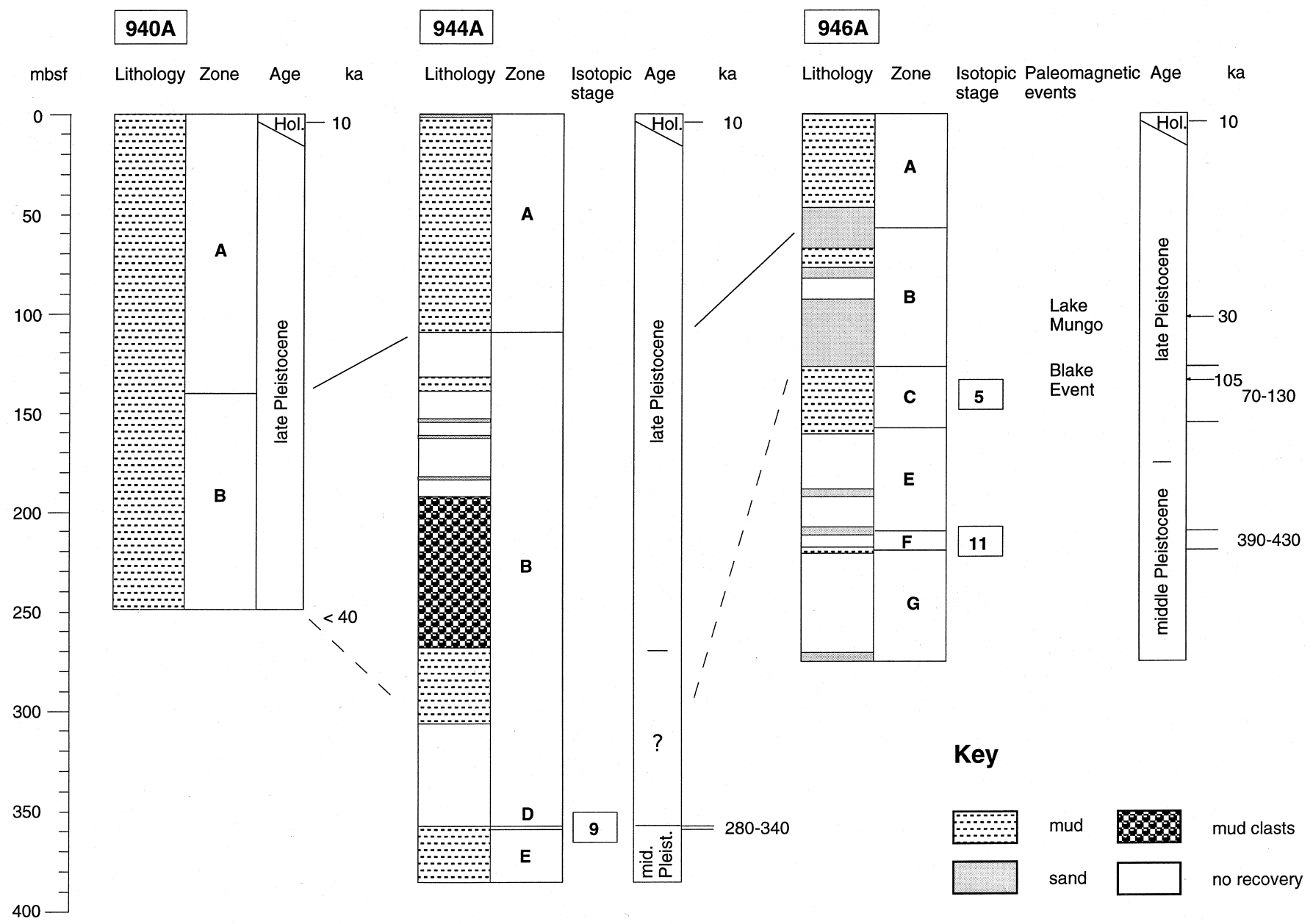

Figure 5. Correlation scheme for Holes 940A, 944A, and 946A based on the palynological zonation. Time control is after Cisowski and Hall (this volume) and Maslin and Mikkelsen (this volume). 